\title{
Denticula jamesrossensis, a new freshwater diatom (Bacillariophyta) species from the Maritime Antarctic Region
}

\author{
Bart Van de ViJver ${ }^{1,2}$, Kateřina Kopalová ${ }^{3}$, J. Patrick KocioleK ${ }^{4} \&$ Luc Ector $^{5}$
}

\author{
${ }^{1}$ Botanic Garden Meise, Department of Bryophyta \& Thallophyta, Nieuwelaan 38, B-1860 Meise, Belgium; \\ Corresponding authore-mail: vandevijver@brfgov.be \\ ${ }^{2}$ University of Antwerp, Department of Biology, ECOBE, Universiteitsplein 1, B-2610 Wilrijk, Antwerpen, Bel- \\ gium \\ ${ }^{3}$ Charles University in Prague, Faculty of Science, Department of Ecology, Viničná 7, CZ-12844 Prague 2, \\ Czech Republic \\ ${ }^{4}$ University of Colorado Museum of Natural History and Department of Ecology and Evolutionary Biology, \\ University of Colorado, Boulder, Colorado 80309, USA \\ ${ }^{5}$ Luxembourg Institute of Science and Technology (LIST), Department 'Environmental Research and Innova- \\ tion'(ERIN), rue du Brill 41, L-4422 Belvaux, Luxembourg
}

\begin{abstract}
During a survey of the freshwater diatom flora of James Ross Island (northern Weddell Sea) in the Maritime Antarctic Region, an unknown Denticula taxon was found in some lakes of Clearwater Mesa. The taxon showed some similarities with D. rainierensis Sovereign and D. subtilis Grunow but based on detailed light (LM) and scanning electron microscopy (SEM) the species showed sufficient morphological differences to separate it as a new species: $D$. jamesrossensis sp. nov. The new taxon is characterized, and distinguished from other species of the genus, by a typical constriction in the middle of the valve and a very high number of striae (up to 60 in $10 \mu \mathrm{m}$ ). So far, the new taxon has only been found on James Ross Island where it occurs in alkaline lakes with high specific conductance values.
\end{abstract}

Key words: Denticula, Maritime Antarctic Region, morphology, new species

\section{INTRODUCTION}

During the past few years taxonomic research in the Antarctic Region has significantly intensified resulting in the description of a large number of new and most likely endemic taxa from a wide variety of genera such as Muelleria (Frengueldi) Frengueldi (SpauldING et al. 1999; VAN DE VIJVER et al. 2010, 2014), Luticola D.G.Mann (Kopalová et al. 2011; Zidarova et al. 2014), Navicula Bory (VAn DE VIJVER et al. 2011), Pinnularia EhrenB. (ZidArova et al. 2012) and Stauroneis EhrenB. (ZiDAROva et al. 2014). Compared to this high number of endemic Antarctic taxa, the number of new Bacillariales taxa for the Antarctic Region is very low and restricted to some new taxa in the genera Nitzschia Hassall and Hantzschia Grunow. The first Antarctic freshwater nitzschioid diatom to be described was Fragilaria tenuicollis var. antarctica W. et G.S.WEST in 1911 (later transferred to Nitzschia westii D.E.KellogG et al. in 1980 and corrected to Nitszchia westiorum in VAN DE VIJVER et al. 2012). BOURRELLY \& Manguin (1954) published three new diatoms from the sub-Antarctic Îles Kerguelen including one Denticula KÜTz. taxon: Denticula elegans var. robusta MANGUIN. Almost fifty years later, VAN DE VIJVER et al. (2002) described Nitzschia chardezii VAN DE VIJVER et BeYENS and Hantzschia possessionensis VAN DE VIJVER et BEyEns. The largest contribution to new nitzschioid diatoms in the region so far was ZiDAROVA et al. (2010), who described five new taxa from the genus Hantzschia from Livingston Island. Until now however, no new freshwater taxa of Denticula have been described from the Maritime Antarctic Region.

Although originally only freshwater taxa were included within the genus Denticula, nowadays, the genus comprises a lot of marine and brackish taxa, several of which were transferred to the fossil genera Crucidenticula (AKIBA \& YANAGISAWA 1985) and Neodenticula (AKIBA \& YANAGISAWA 1985) and the extant genera Denticulopsis (SIMONSEN 1979), Nagumoea Witkowski et Kociolek (in Witkowski et al. 2011) and Tetralunata (Hamsher, GraefF, StePaneK \& KocioleK 2014). Hamsher et al. (2014) reviewed the taxonomic history of the genus Denticula indicating a total number worldwide for this genus to be around 100 taxa based on the list in Fourtanier \& Kociolek (2011). The number of freshwater taxa of Denticula, however, is limited. Krammer \& Lange-Bertalot (1988) list seven, that number now considered too low as the broad species definition they adopted, placed many validly 
described taxa in synonymy. Since then, new taxa have been described, such as Denticula thermaloides (VAN DE VIJVER \& CocQuYT 2009), but compared to the vas increase in genera such as Pinnularia, Luticola or Amphora Ehrenb. (Levkov 2009; Lange-Bertalot et al. 2011; ZiDAROva et al. 2012; LevKov et al. 2013), the total species number in this genus remains low.

Some of the freshwater taxa, such as Denticula tenuis KüTz. and D. kuetzingii GruNow, are widespread in the Arctic Region (Greenland, Spitsbergen, Ellesmere Island) forming often large populations in lake and wet moss vegetation (Douglas \& Smol 1993; VaN DE VIJVER et al. 1999, 2003; ANTONIADES et al. 2008). On the contrary, in the Antarctic Region, Denticula is almost completely absent and so far only reported in very low abundances from some sub-Antarctic island in the southern Indian Ocean (VAN DE VIJVER et al 2002). Kellogg \& Kellogg (2002) list only one species present in a handful of papers published on Antarctic localities.

During a survey of the lacustrine diatom flora of James Ross Island, located in the northern Weddel Sea, several very large Denticula populations were discovered. In some investigated lakes, more than $90 \%$ of all counted valves belonged to this taxon. Using the currently available literature, it was however impossible to identify these populations and after careful comparison with similar taxa, these populations are described here as Denticula jamesrossensis sp. nov. and its morphological variability is documented using light- (LM) and scanning electron (SEM) microscope images.

\section{Material and Methods}

During a survey of non-marine diatoms from James Ross Sland, a series of samples collected on Clearwater Mesa, (= tableland) composed of single hyaloclastite breccia unit capped with subaerial basalt of the James Ross Island Volcanic Group (NeLson 1975; KošLer et al. 2009). The volcanic rocks of the Clearwater Mesa delta have not been dated directly, but the age of the adjoining Förster Cliffs main delt (2.50 \pm 0.07 Ma; SMELLE et al. 2008) shows on the earliest Pleistocene age of this subglacial volcanic phase and could be et al. 1996). On the flat mesa surface (mostly $250-300 \mathrm{~m}$ a.s.l.) tens of lakes evolved after the glacier retreat during the early Holocene (NedBaloví et al. 2013). These lakes are generally shallow with a maximum depth of a few meters and could be regarded as permanent and old with a persistence of thousands of years. Their littoral zone is covered by microbial mats dominated by filamentous cyanobacteria.

Diatom samples for LM observation were prepared following the method described in VAN DER WERFF (1955), and heating to $80^{\circ} \mathrm{C}$ for about $1 \mathrm{~h}$. The reaction was complet-

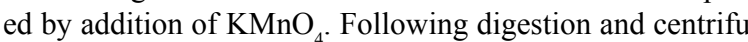
gation (three times 10 minutes at $3700 \times \mathrm{g}$ ), cleaned material was diluted with distilled water to avoid excessive concentrations of diatom valves on the slides. Cleaned diatom mthial was mounted in Naphrax. The slides were analysed using an Olympus BX53 microscope, equipped with Diffe I Soft Imaging System. Samples and slides are stored at the BR-collection, property of the Belgian federal government and given in permanent loan to the Botanic Garden Meise (Belgium). For SEM, parts of the oxidized suspensions were filtered through polycarbonate membrane filters with a pore diameter of $1 \mu \mathrm{m}$, pieces of which were fixed on aluminium stubs after air-drying. The stubs were sputter-coated with a Gold-Palladium layer of $20 \mathrm{~nm}$ and studied in a ZEIS ULTRA SEM microscope at $3 \mathrm{kV}$ (Natural History Museum Round et al (1990). The morphology of the new species has been compared to the ultrastructure of several described tax (Sovereign 1963; Archibald 1982; Krammer \& Lange-Bertalot 1988; LANGe-Bertalot \& Krammer 1993; Johansen e al. 1994; HAMSHER et al. 2014).

\section{Results}

\section{Division Bacillariophyta}

Class Bacillariophyceae HAECKEL emend. MEDLIN \& KACZMARSKA 2004

Sacillariophycidae D.G.MANN in Round et al. 1990

(1937

Genus Denticula Küтz. 1844

Denticula jamesrossensis sp. nov. (Figs 1-30)

Light microscopy (Figs 1-22): Frustules rectangular in girdle view (Figs 1, 2). Costae weakly or not capitate in girdle view (Figs 1,2). Valves strictly linear (= never linear to linear-lanceolate) with parallel margin and non-protracted, bluntly rounded to wedge-shaped apices. Most valves with a clear constriction nea the valve middle. Valve dimensions $(n=20)$ : length 13.0-19.5 $\mu \mathrm{m}$, width $2.8-3.3 \mu \mathrm{m}$, length/width ratio 4.0-7.4. Raphe near the margin, not discernible in LM. Costae, 9-10 in $10 \mu \mathrm{m}$, running parallel to each other throughout the entire valve, slightly more radiate near the apices. Striae not visible in LM. SEM (Figs 23-30): Girdle composed of open copulae bearing one row of small, rounded poroids (Fig. 30). Valvocopula showing an undulating pars interior with undulations covering the onset near the margins of the transapical costae (Fig. 30). Edge of valve mantle covered by a continuous series of small siliceous wraths giving the edge dentate appearance, well visible on internal views (Fig. 24). Striae, ca. 60 in $10 \mu \mathrm{m}$, grouped externally in series of 3-6 rows of areolae, alternating with paralle hyaline zones formed by neighbouring costae (Fig. 23). Striae composed of a series of small, rounded areolae, the outer striae in each group showing the largest areolae (Fig. 23). Near the axial area bearing the raphe, a continuous longitudinal series of enlarged, rounded areolae present, bordering that way the axial area (Figs 23, 25). Striae interrupted near the axial area bearing the raphe and continuing on the mantle as small porefields with up to 6-8 rounded areolae arranged in small descending triangles (Fig. 25). On the other valve margin, continuous longitudinal series of areolae lacking, replaced by a very narrow hyaline zone. Striae continuing on the valve mantle as small porefields (Fig. 23). Costae externally usually not or only slightly narrowing near the margin opposite the raphe. Internally costae clearly developed, thickened near both margins, always more on the raphe-bearing margin than on the opposite site (Figs 27, 29). Coastal thickenings bridging over the raphe canal (Fig. 29) on the raphe-bearing margin Occasionally, costal thickenings on the raphe-bearing margin joined by shallow thickenings (Fig. 29) Height of the costae lower in the middle than near the margins (Fig. 27). Raphe always in an eccentric position, located on the edge of the valve face (Fig. 23). Raphe branches straight with straight, almost not expanded proximal raphe endings, separated ca. $0.1 \mu \mathrm{m}$ from each other (Fig. 25). Distal raphe fissures clearly deflected, expanded near the ends (Fig. 26). Internally, raphe running between two very weakly raised ridges (Figs 28, 29). Proximal endings separated by small ing on small helictoglossae (Fig. 28).

Etymology: The species is named after James Ross Etymology: The species is named after James Ross
Island where the new species was described from. Up Island where the new species was described from. Up
to now, the new species has only been found on this

ype locality: Antarctica, James Ross Island, Clear-

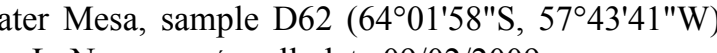
4346 (Botanic Garen Meise, Belgium).

) Antwerp, Belgium).

Ecology and Distribution: Denticula jamesrossensis has been found only on James Ross Island. The largest opulation was observed on the Clearwater Mesa. Its distribution on other Maritime or Continental Antarctic

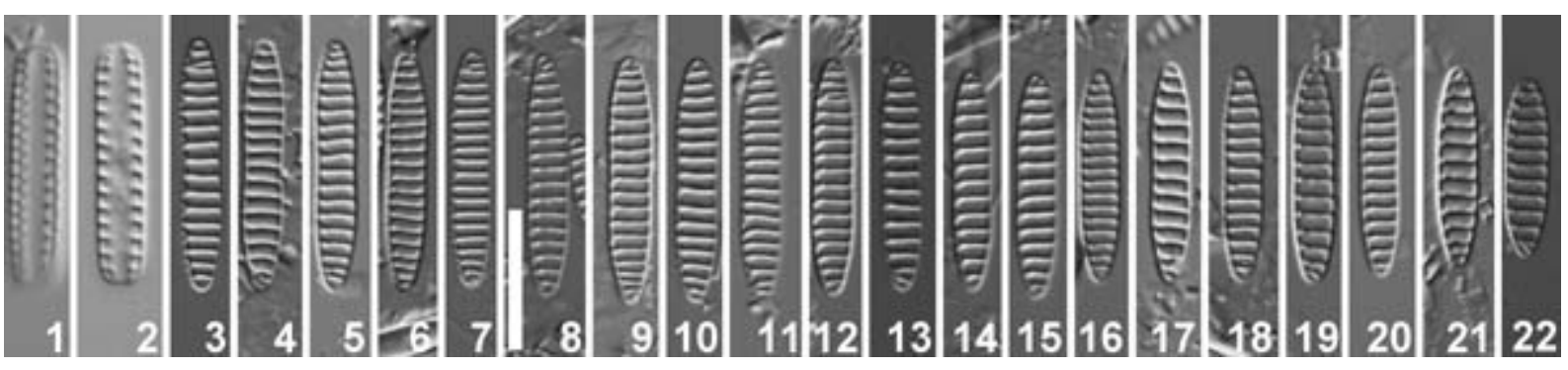

Figs 1-22. LM: Denticula jamesrossensis, all images from holotype slide
views showing variation in size and valve outline. LM scale bar $10 \mu \mathrm{m}$. localities is at present unknown. The largest population (Denticula jamesrossensis was found in two samples 列 details on lake types on James Ross Island), altitude a.s.l., max. depth $0.5 \mathrm{~m}$, with an alkaline $\mathrm{pH}$ , (T). and low nutrient values (Total Phosphorus = $17.9 \mu \mathrm{g} .1 \mathrm{I})$. The samples were dominated by Denticula

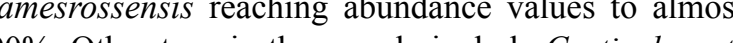
ande include Craticula antalcolamphora oligo-

\section{Discussion}

There are only a few small-celled, finely striated freshwater or brackish Denticula taxa known worldwide. A total of 5 species, including $D$. jamesrossensis, can al be included in a subgroup within the genus Denticula, as recognized in 1993 by LANGE-BerTALOT \& KRAMMER between the families Bacillariaceae and Epithemiaceae. All species in this subgroup show an eccentric raphe, a feature usually found in the genus Nitzschia, and have distinct costae and an adaptation of the valcenus Denticula. Whether they should be sepor the from Denticula and Nitzschia as a separate genus is at research will be necessary to reveal the correct taxonomic position of these taxa.

The group of species related to $D$. tenuis, another smaller freshwater Denticula species, can be being situated on a distinct raphe keel on the valve face instead of being entirely eccentric and the presence of typical capitate costae in girdle view.

Although all taxa from this subgroup show some similarity with $D$. jamesrossensis, they can be separated based on a combination of morphological differences. The most similar taxon is $D$. rainierensis, described in 1963 by SovereIGN from Ohanapecosh (epilicic and epipelic) from the littoral zone of a staa present not clear and thorough molecular or cladistic 


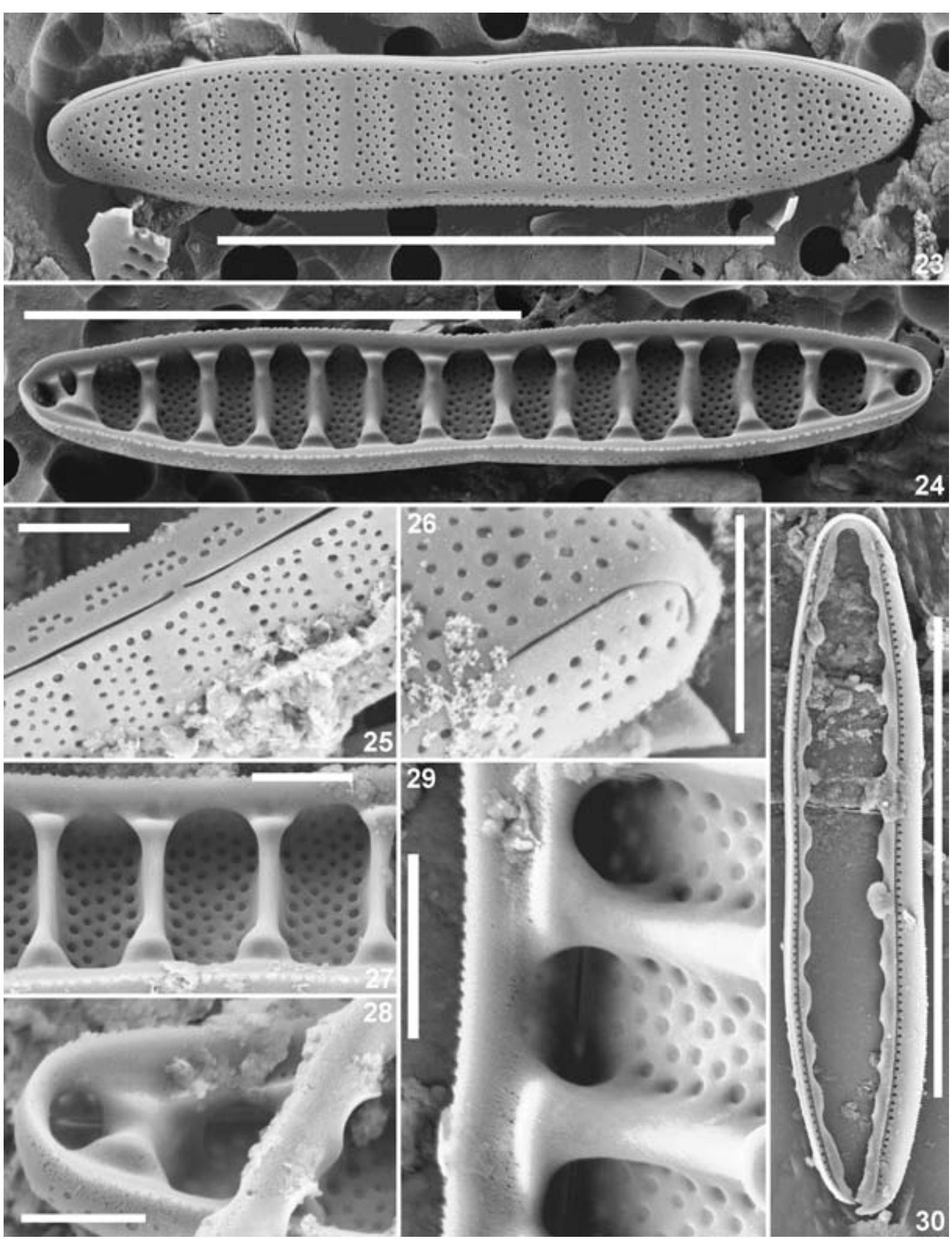

Figs 23-30. SEM: Denticula jamesrossensis, all pictures taken from holotype material, (23) External view of entire valve showing raphe and
stria structure, (24) Internal view of entire valve showing arrangement of costae and striae. Note silica dentation on mantle edge, (25) External stria structure, (24) Internal view of entire valve showing arrangement of costae and striae. Note silica dentatiton on mantle edge, (25) Externa
detail of central area with straight proximal raphe endings, (26) External detail of valve apex with defflected distal raphe fissure, (27) Internal central nodule end proximal raphe endings, (30) Entire valvocopula showing undulated pars interior and single row of small pores. SEM scale bar $1 \mu \mathrm{m}(25-29), 10 \mu \mathrm{m}(23,24,30)$
Hot Springs, USA. Initially, KRAMMER \& LANGE-BERTALOT (1988) considered it to be a synonym of $D$. sub tilis but after a detailed study of its ultrastructure by OHANSEN et al. (1994), both taxa were separated again. Denticula jamesrossensis can be distinguished from D. rainierensis in having slight larger valves $(8-16.5$ vs. $13-19 \mu \mathrm{m})$, a larger length/width ratio giving the valves a more slender, elongate outlook, a strictly linear valve outline compared to the more linear-lanceolate to elliptic-lanceolate valve outline of $D$. rainierensis, the presence of a clear constriction in the valve
middle of $D$. jamesrossensis and a higher number of striae (ca. 60 vs. 45-52 in $10 \mu \mathrm{m}$ ) (see also HAMSHER et al. 2014). Denticula rainierensis shows a comparable morphology to $D$. creticola (ØStRuP) LANGe-BERTaLoT et Krammer. Lange-Bertalot \& Krammer (1993) suggested a possible conspecificity between these two species but refrained from taking a clear decision. Based on the LM images taken from the holotype of $D$. cre ticola presented in their paper, it is clear that the latter shows some similarities with $D$. jamesrossensis but can be separated based on the following features: the valves of $D$. creticola have a more elliptic-lanceolate valve outline with more rounded apices, always lacking a constriction in the valve middle; the valves are usually smaller $(<15 \mu \mathrm{m})$. ØsTRUP (1910) mention only 10 striae in $10 \mu \mathrm{m}$ but most likely this refers to the number of costae. Based on figure 36 in LANGE-BERTALOT \& KRAMMER (1993) from a valve found in Ukraine, the striae are grouped with a maximum of 6 striae per group, similar to $D$. jamesrossensis. Based on the same figure, the proximal raphe endings are apparently also much less separated than in D. jamesrossensis. Two other small-celled freshwater Denticula taxa are $D$. subtilis and D. sundaysensis ARCHIBALD. Both taxa have a clearly lanceolate to linear-lanceolate valve outline with a lower number of striae (26-30 in $10 \mu \mathrm{m}$ ) which are discernible in LM and is almost half the number of striae in $D$. jamesrossensis. Denticula sundaysensis has typically only two rows of areolae between the costae contrary to the 3-6 rows in D. jamesrossensis. On the sub-Antarctic Ile de la Possession (Crozet Archipelago) in the southern Indian Ocean, VAN DE VIJVER et al. (2002) report the presence of a small population of $D$. sundaysensis but the population is not conspecific with $D$. jamesrossensis being much smaller with only two rows of areolae between the costae.

Additionally, ecological differences can be noted between the different species mentioned above Denticula rainierensis was originally described from a hot spring in the state of Washington (western USA). The species was also found, as was $D$. creticola, on wet walls (Johansen et al. 1994) although LANGe-BerTALOT \& KRAMmER (1993) also reported their presence in brackish waters. Denticula jamesrossensis was typically found in alkaline lakes with very high specific conductance values and higher chloride values (up to $\left.181 \mathrm{mg} . .^{-1}\right)$. The two other taxa, D. subtilis and D. sun- daysensis are typical brackish taxa.

ACKNowLEDGEMENTS

This work was supported by the projects KONTAKT ME 945, Czech to thank the members of expeditions to the Czech Antand also like "J.G. MeNDEL" for providing the samples. LINDA NedBaloví and DANIEL NyvLt are thanked for their information on the Clearwater Mesa sample. This study was further supported by the BELSPO

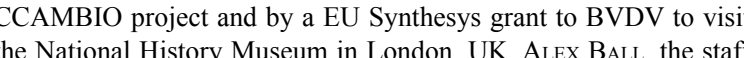
of the IAC laboratory are thanked for their help with the scannin electron microscopy.

\section{REFERENCES}

AKiba, F. \& YanaGisawa, Y. (1985): Taxonomy, morphology and phylogeny of the Neogene diatom zonal marker Pacific. - In: KagaMI, H.; Karig, D.E.; CourourN, W.T. et al. (eds): Initial Reports of the Deep Sea Drilling Project, vol. 87. - pp. 483-554, U.S. Government Printing Office, Washington.

Antoniades, D.; Hamilton, P.B.; Douglas, M.S.V. \& SMo J.P. (2008): Diatoms of North America: The freshwater floras of Prince Patrick, Ellef Ringnes and northern Ellesmere Islands from the Canadian Arctic A-

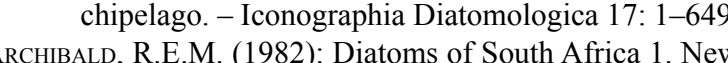
species from the Sundays River (Eastern Cape Province). - Bacillaria 5: 23-42.

BourReLLY, P. \& MANGUIN, E. (1954): Contribution à la flore algale d'eau douce des Iles Kerguelen. - Mémoires de l'Institut Scientifique de Madagascar, Série B, 5 :

7-58.
DougLAS, M.S.V. \& SMoL, J.P. (1993): Freshwater diatoms from high Arctic ponds (Cape Herschel, Ellesmere

PENBERG, C. . (1831): Über die Entickelung bensdauer der Infusionsthiere; nebst ferneren Beitrigen zu einer Vergleichung ihrer organischen Systeme. - Abhandlungen der Königlichen Akademie der Wissenschaften zu Berlin 1831: 1-154.

FoURTANIER, E. \& KOCIOLEK, J.P. (2011): Catalogue of Diatom Names, California Academy of Sciences, On-line Version updated 19 Sept. 2011. - Available online at http://research.calacademy.org/research/diatom names/index.asp

MSHe, S.A.; GRafF, C.L.; Stepanek, J.G. \& Kociolek, J.P. (2014): Frustular morphology and polyphyly in
freshwater Denticula (Bacillariophyceae) species, and the description of Tetralunata gen. nov. (Epithemiaceae, Rhopalodiales). - Plant Ecology and Evolution 147: 346-365.

HENDEY, N.I. (1937): The plankton diatoms of the souther

seas. - Discovery Reports 16: 151-364. amination of type material of Denticula rainierensis the 11th International Diatom Symposium - Memoirs of the California Academy of Sciences 17: 211219. 
(1980): Non-marine diatoms from Late Wisconsin perched deltas in Taylor Valley, Antarctica. - Palaeogeography, Palaeoclimatology, Palaeoecology 30:

KellogG, T.B. \& KellogG, D.E. (2002): Non-marine and littoral diatoms from Antarctic and Subantarctic reMonographs 1: 1-795.

Kopaloví, K.; Nedbaloví, L;; de HaAn, M. \& Van de VIJVER, B. (2011): Description of five new species of the diatom genus Luticola (Bacillariophyta, Diadesmidaceae) found in lakes of James Ross Island (Maritime Antarctic Region).- - Phytotaxa 27: 44-60.

Košler, J.; Magna, T.; MLČoch, B.; Mixa, P.; NÝvlt, D. \& Hocus, F.V. (2009): Combined $\mathrm{Sr}, \mathrm{Nd}, \mathrm{Pb}$ and $\mathrm{Li}$ James Ross Island (Antarctic Peninsula) and implications for back-arc magma formation. - Chemical Geology 258: 207-218.

Krammer, K. \& LANGe-Bertalot, H. (1988): Bacillariophyceae 2. Teil: Bacillariaceae, Epithemiaceae, Surirellaceae. - In: ETTL, H.; GerLoff, J.; HeYNIG, H. \& MoLLENHAUER, D. (eds): Süsswasserffora von Mitte-
leuropa, Band 2/2. 596 pp., Gustav Fischer Verlag, Stuttgart, New York

KüTzING, F.T. (1844): Die kieselschaligen Bacillarien oder Diatomeen.- Nordhausen, 152 pp, 30 pls.

Lange-Bertalot, H. \& Krammer, K. (1993): Observation on Simonsenia and some small species of Denticula and Nitzschia. - Nova Hedwigia, Beiheft 106: $121-$ 131.

Lange-Bertalot, H.; BaK, M. \& Witkowski, A. (2011): Eunotia and some related genera. - Diatoms of Europe

LEVKov, Z. (2009): Amphora sensu lato. - Diatoms of Europe $5: 1-916$

Levkov, Z.; Metzetin, D. \& Pavlov, A. (2013): Luticola and Luticolopsis. - Diatoms of Europe 7: 1-697.

MEDLIN, L.K. \& KACZMARSKA, I. (2004): Evolution of the diatoms: V. Morphological and cytological support for the major clades and a taxonomic revision. - Phyco-
logia 43: 245-270. (2)

TopíčEK, J.; Šobr, M. \& Elster, J. (2013): Freshwater lakes of Ulu Peninsula, Jame Ross Island, north-east Antarctic Peninsula: origin, ogy. - Antarctic Science 25: 358-372.

Nelson, P.H.H. (1975): The James Ross Island Volcanic Group of north-east Graham Land. - British Antarctic Survey Scientific Reports 54: 1-62.

ØstruP, E. (1910): Danske Diatoméer. - 323 pp., 5 pls., C.A.

Reitzels Boghandel, Kjøbenhavn.
Round, F.E.; CrawFord, R.M. \& MAnN, D.G. (1990): The 747 pp. Cambridge University Press. Cambridge.

Simonsen, R. (1979): The diatom system: ideas on phylog-

eny. - Bacillaria 2: 9-71.
Smelie, J.L.; PAllàs, R.; SÁBat, F. \& Zheng, X. (1996): Age and correlation of volcanism in central Livingston Island, South Shetland Islands. K-Ar and geochemical ences 9: 265-272.
entrints - Jounal American Earth SciSMelLie, J.L.; Johnson, JS VURMUSDSB. (2008): Six million years of glacial history recorded volcanic lithofacies of the James Ross Isgeography, Palaeoclimatology, Palaeoecology 260

SOVREIGN, H.E. (1963): New and rare diatoms from Oregon and Washington. - Proceedings of the Californ
Academy of Sciences, Fourth series $31: 349-368$.

SPAULDING, S.A.; Kociolek, J.P. \& Wong, D. (1999) A taxonomic and systematic revision of the genus Muelle-
ria (Bacillariophyta). - Phycologia 38: 314-341.

VAN DER WERFF, A. (1955): A new method of concentrating
and cleaning diatoms and other organisms. - Verand cleaning diatoms and other organisms. - Ver-
handlungen der Internationalen Vereinigung für Theoretische und Angewandte Limnologie 2: 276-277.

VAN DE VIVER, B. \& COCQUYT, C. (2009): Four new diato species from La Calera hot spring in the Peruviaa 223.

Van de Vijver, B.; Ledeganck, P.; Potters, G. \& Beyens, L. (1999): Diatom communities from alkaline environments of the Brøgger Peninsula, north-west Spitsbergen. - Nova Hedwigia 68: 93-115.

Y. \& Beyens, L. (2002): Freshwapersession (Crozet Arch46: $1-412$.

Van de ViJver, B.; Van Kerckvoorde, A. \& Beyens, L. (2003): Freshwater and terrestrial moss diatom assemblages of the Cambridge Bay area, Victoria Island (Nunavul, Canada). - Nova Hedwigia 76: 225-243, an de ViJver, B.; Matalon, G.; Stanish, L. \& Spaulding, S.A. (201). New and interesting species of the geregion and South Africa - Phycologia 49: 22-41.

Van de Vijver, B.; Zidarova, R.; Sterken, M.; Verleyen, E; de HaAn, M.; Vyverman, W.; Hinz, F. \& Sabbe, K. (2011): Revision of the genus Navicula s.s. (Bacillariophyceae) in inland waters of the Sub-Antarctic and Antarctic with the description of five new spe-

VAN DE VIJvER, B.; TAVERNIER, I.; KellogG, T.B.; Gibson, J.; Revision of type materials of a SaBBE, K. (2012): cies (Bacillariophyta) described by West \& West Fottea 12: 149-169.

Van de ViJver, B.; Zidarova, R. \& Kopalová, K. (2014) New species in the genus Muelleria (Bacillariophyta) from the Maritime Antarctic Region. - Fottea 14

WEST, W. \& WesT, G.S. (1911): Freshwater algae. - In: MURunder the command of Sir E. H. Shackleton, C. VO. Reports on the Scientific Investigations. Vol 1 Biology. Part VII. - pp. 263-298, William Heinemann, London.

WitrowsKi, A.; KocioleEK, J.P. \& KurZYDŁowski, K.J. (2011) Valve ulrastracture of two new genera, of narine canal-bearing diatoms (Bacillariophyceae). - Phycolo-

Zidarova, R.; VAN DE VIJver, B.; QuesadA, A. \& de HaAn, M. (2010): Revision of the genus Hantzschia (BacilIslands, Southern Atlantic Ocean). - Plant Ecology and Evolution 143: 318-333.
Zidarova, R.; Kopalová, K. \& VAn de Viveer, B. (2012): The genus Pinnularia (Bacillariophyta) excluding the section Distantes on Livingston Island (South Shet- Phytotaxa 44: 11-37.

Zidarova, R.; Kopalová, K. \& VAn de ViJver, B. (2014): The genus Stauroneis (Bacillariophyta) from the South Shetland Islands and James Ross Island (Antarctica) - Fottea 14: 201-207.

OCzech Phycological Society (2015)

Received December 12, 2014
Accepted January 15, 2015 